\title{
Pengaruh self efficacy dan pengasuhan orang tua terhadap kepercayaan diri siswa
}

\author{
Chairunnisa Pangestu*, Hieronimus Sujati, Herwin Herwin \\ Pendidikan Sekolah Dasar, Fakultas Ilmu Pendidikan, Universitas Negeri Yogyakarta \\ *Corresponding Author. e-mail: chairunnisapangestu.2017@ student.uny.ac.id
}

\begin{abstract}
Abstrak
Penelitian ini bertujuan untuk mengetahui secara parsial pengaruh self efficacy terhadap sikap percaya diri, mengetahui secara parsial pengaruh pengasuhan orang tua terhadap sikap percaya diri, serta mengetahui secara simultan pengaruh self efficacy dan pengasuhan orang tua terhadap sikap percaya diri. Penelitian ini menggunakan pendekatan kuantitatif dengan metode ex-post facto. Populasi dalam penelitian ini adalah siswa SD se-Kecamatan Kotagede, Yogyakarta yang berjumlah 3941 siswa dengan sampel penelitian berjumlah 363 siswa yang ditentukan dengan Metode Slovin. Teknik pengumpulan data menggunakan skala kepercayaan diri, skala self efficacy, dan skala pengasuhan orang tua. Uji prasyarat analisis menggunakan uji normalitas, uji linearitas dan uji multikolinearitas. Teknik analisis data yang digunakan adalah korelasi parsial dan regresi ganda. Hasil penelitian menunjukkan bahwa self efficacy secara parsial berpengaruh signifikan terhadap kepercayaan diri siswa, pengasuhan orang tua secara parsial berpengaruh secara signifikan terhadap kepercayaan diri siswa, serta self efficacy dan pengasuhan orang tua secara simultan berpengaruh signifikan terhadap kepercayaan diri siswa dengan sumbangan sebesar 35,5\%.
\end{abstract}

Kata kunci: self efficacy, pengasuhan orang tua, percaya diri

\begin{abstract}
This study aims to partially determine the effect of self-efficacy on self-confidence, partially know the effect of parenting on self-confidence, as well as knowing simultaneously the effect of self-efficacy and parenting of parents on self-confidence. This research uses a quantitative approach with ex-post facto methods. The population in this study were elementary school students in Kotagede District, Yogyakarta, which amounted to 3941 students with a sample of 363 students determined by the Slovin Method. Data collection techniques using a scale of self-confidence, self-efficacy scale, and parenting scale. The analysis prerequisite test uses normality test, linearity test and multicollinearity test. Data analysis techniques used are partial correlation and multiple regression. The results showed that self efficacy partially had a significant effect on student confidence, parental care had a partially significant effect on student confidence, and self efficacy and parenting simultaneously had a significant effect on student confidence with a contribution of $35.5 \%$.
\end{abstract}

Keywords: self efficacy, parenting, confident

This is an open-access article under the CC-BY-SA license.

How to Cite: Pangestu, C., Sujati, H., Herwin, H. (2020). Pengaruh self efficacy dan pengasuhan orang tua terhadap keercayaan diri siswa. FOUNDASIA, 11(1), 35-42. 


\section{PENDAHULUAN}

Undang-undang RI No. 20 tahun 2003, tentang sistem pendidikan nasional pasal 3 dijelaskan bahwa "Pendidikan nasional berfungsi mengembangkan kemampuan dan membentuk watak serta peradaban bangsa yang bermartabat dalam rangka mencerdaskan kehidupan bangsa, bertujuan untuk berkembangnya potensi peserta didik agar menjadi manusia yang beriman dan bertaqwa kepada Tuhan Yang Maha Esa, berakhlak mulia, sehat, berilmu, cakap, kreatif, mandiri, dan menjadi warga negara yang demokratis serta bertanggung jawab". Berdasarkan observasi dan wawancara dengan guru dan siswa di SD yang dijadikan sebagai sampel se-Kecamatan Kotagede diperoleh informasi mengenai permasalahan-permasalahan yang muncul. Permasalahan tersebut antara lain kurangnya kepercayaan diri siswa, kurangnya kesadaran akan kemampuan dirinya, kecenderungan ragu-ragu atau malu-malu, serta kurangnya rasa keberanian siswa.

Kurangnya kepercayaan diri siswa dibuktikan saat diminta guru untuk menjawab pertanyaan, siswa cenderung menjawab dengan suara pelan karena kurang percaya diri akan jawabannya. Saat bernyanyi, siswa cenderung bernyanyi dengan suara pelan, meskipun siswa tersebut sudah hafal lirik lagunya. Selain itu, kurangnya kesadaran akan kemampuannya dibuktikan pada saat membaca teks bacaan, siswa cenderung membaca teks dengan suara pelan, karena tidak yakin dengan kemampuannya membaca teks. Siswa cenderung takut salah dalam membaca teks. Lebih lanjut, ragu-ragu pada siswa ini dibuktikan dengan kecenderungan siswa selalu menanyakan dimana harus menulis jawaban pada soal, siswa ragu-ragu saat menanyakan materi yang dijelaskan guru apabila kurang jelas atau kurang terdengar.

Hal tersebut menunjukkan bahwa ada beberapa permasalahan yang terjadi di beberapa SD di kecamatan Kotagede. Melihat luasnya permasalahan tersebut, lingkup penelitian dibatasi pada rendahnya kepercayaan diri siswa. Satiadarma (2000: 245) menjelaskan bahwa rasa percaya diri (self confidence) erat kaitannya dengan falsafah pemenuhan diri (self-fulfilling prophesy) dan keyakinan diri (self efficacy). Apabila seseorang yakin akan kemampuan yang ada dalam dirinya, maka ia juga akan merasa percaya diri dalam menjalankan kegiatannya.

Kepercayaan diri merupakan hal yang paling berharga pada diri individu dalam kehidupan bermasyarakat. Hal ini disebabkan karena dengan kepercayaan diri, seseorang mampu mengaktualisasikan segala potensi dirinya. Kepercayaan diri seseorang adalah sebuah ekspresi atau ungkapan didasari dengan rasa semangat dan mengesankan dan dalam diri individu untuk menunjukkan adanya harga diri, penghargaan terhadap diri, serta bagaimana seseorang memahami dirinya sendiri (Yoder \& Procter, 1998:4).

Ada banyak faktor yang mempengaruhi kepercayaan diri seseorang. Ada faktor yang berasal dari diri individu (internal) dan faktor diluar individu tesebut (eksternal). Faktor Internal, meliputi: (1) Konsep diri, yakni terbentuknya kepercayaan diri pada seseorang diawali dengan perkembangan konsep diri yang diperoleh dalam pergaulan suatu kelompok. Konsep diri merupakan gagasan tentang dirinya sendiri. Seseorang yang mempunyai rasa rendah diri biasanya mempunyai konsep diri negatif, sebaliknya orang yang mempunyai rasa percaya diri akan memiliki konsep diri positif. (2) Harga diri, yaitu penilaian yang dilakukan terhadap diri sendiri. Orang yang memiliki harga diri tinggi akan menilai pribadi secara rasional dan benar bagi dirinya serta mudah mengadakan hubungan dengan individu lain. Orang yang mempunyai harga diri tinggi cenderung melihat dirinya sebagai individu yang berhasil percaya bahwa usahanya mudah menerima orang lain sebagaimana menerima dirinya sendiri. Akan tetapi orang yang mempuyai harga diri rendah bersifat tergantung, kurang percaya diri dan biasanya terbentur pada kesulitan sosial serta pesimis dalam pergaulan. (3) Kondisi fisik, yaitu perubahan kondisi fisik juga berpengaruh pada kepercayaan diri. Menurut Anthony, mengatakan penampilan fisik merupakan penyebab utama rendahnya harga diri dan percaya diri seseorang. (4) Pengalaman hidup, yakni kepercayaan diri diperoleh dari pengalaman yang mengecewakan adalah paling sering menjadi sumber timbulnya rasa rendah diri. Lebih lebih jika pada dasarnya seseorang memiliki rasa tidak aman, kurang kasih sayang dan kurang perhatian (Ghufron \& Rini, 2011: 37).

Selain faktor internal, terdapat juga faktor eksternal yang mempengaruhi, meliputi: (1) Pendidikan, mempengaruhi kepercayaan diri seseorang, tingkat pendidikan yang rendah cenderung membuat individu merasa dibawah kekuasaan yang lebih pandai, sebaliknya individu yang 
pendidikannya lebih tinggi cenderung akan menjadi mandiri dan tidak perlu bergantung pada individu lain. Individu tersebut akan mampu memenuhi keperluan hidup dengan rasa percaya diri dan kekuatannya dengan memperhatikan situasi dari sudut kenyataan Ghufron \& Rini, 2011: 38). (2) Pekerjaan, Kusuma mengemukakan bahwa bekerja dapat mengembangkan kreatifitas dan kemandirian serta rasa percaya diri. Lebih lanjut dikemukakan bahwa rasa percaya diri dapat muncul dengan melakukan pekerjaan, selain materi yang diperoleh. Kepuasan dan rasa bangga didapat karena mampu mengembangkan kemampuan diri. (3) Lingkungan, merupakan lingkungan keluarga dan masyarakat. Dukungan yang baik yang diterima dari lingkungan keluarga seperti anggota kelurga yang saling berinteraksi dengan baik akan memberi rasa nyaman dan percaya diri yang tinggi. Begitu juga dengan lingkungan masyarakat semakin bisa memenuhi norma dan diterima oleh masyarakat, maka semakin lancar harga diri berkembang.

Berdasarkan penjelasan tersebut, diketahui bahwa keyakinan akan diri sendiri (self efficacy) serta faktor keluarga mempengaruhi kepercayaan diri individu. Anwar (2009: 23) menyatakan bahwa self efficacy merupakan hal yang memiliki peranan yang sangat penting dalam mempengaruhi segala usaha setiap orang, seberapa tinggi upaya seseorang dalam memprediksi keberhasilan yang dia akan dicapai. Lebih lanjut self-effiacy dimaknai sebagai penilaian individu terhadap dirinya atau tingkat keyakinan tentang kemampuan seseorang untuk melakukan sesuatu dalam mencapai hasil atau tujuan tertentu.

Self efficacy pada anak juga dipengaruhi oleh pola pengasuhan yang diterima dari orang tua. Setiap anak harus mendapatkan pengetahuan tentang kemampuan diri mereka dalam mengembangkan kemampuan diri mereka. Pengalaman pertama yang diterima anak adalah dari keluarga. Tetapi dalam perkembangannya, dunia sosial anak berkembang dengan cepat yang dipengaruhi juga oleh teman sebaya sehingga anak mampu mengembangkan kemampuan diri mereka.

\section{METODE PENELITIAN}

Penelitian ini menggunakan pendekatan penelitian kuantitatif. Jenis penelitian yang digunakan adalah ex-post facto. Penelitian ini dilakukan di SD Kecamatan Kotagede, Yogyakarta, Daerah Istimewa Yogyakarta. Populasi dalam penelitian ini adalah siswa SD se-Kecamatan Kotagede, Yogyakarta yang berjumlah 3941 siswa dengan sampel penelitian berjumlah 363 siswa yang ditentukan dengan Metode Slovin. Teknik pengumpulan data menggunakan skala skala kepercayaan diri, skala self efficacy, dan skala pengasuhan orang tua. Uji prasyarat analisis menggunakan uji normalitas, uji linearitas dan uji multikolinearitas. Teknik analisis data yang digunakan adalah korelasi parsial dan regresi ganda.

\section{HASIL DAN PEMBAHASAN}

Data dalam penelitian ini dianalisis dengan menggunakan uji prasyarat statistik parametrik dan uji hipotesis. Uji prasyarat analisis yang dilakukan ialah pembuktian normalitas data, linieritas dan multikolinieritas. Uji normalitas dilakukan untuk mengetahui apakah data yang diperoleh berdistribusi normal atau tidak. Pengujian normalitas dilakukan dengan menggunakan Chi Kuadrat yang dihitung menggunakan SPSS versi 22 for windows. Hasil penelitian dikatakan normal apabila nilai Asymp. Sig yang diperoleh >0,05, sedangkan apabila hasil yang diperoleh $\leq 0,05$ maka tidak berdistribusi normal (Saputri \& Herwin, 2020: 119). Berikut ini disajikan pada Tabel 1 ringkasan hasil pengujian normalitas data.

Tabel 1. Ringkasan Hasil Uji Normalitas

\begin{tabular}{llll}
\hline Variabel & Asymp. Sig & Signifikansi & Kesimpulan \\
\hline Kepercayaan Diri & 0,055 & 0,05 & Normal \\
\hline Self Efficacy & 0,057 & 0,05 & Normal \\
\hline Pengasuhan Orang Tua & 0,070 & 0,05 & Normal \\
\hline
\end{tabular}


Berdasarkan hasil pengujian normalitas diperoleh nilai Asymp. Sig untuk variabel kepercayaan diri 0,055, self efficacy 0,057 dan pengasuhan orang tua 0,070. Nilai Asymp. Sig dari ketiga variabel tersebut memiliki nilai di atas 0,05 maka distribusi data dari setiap variabel dikatakan normal.

Uji linieritas dilakukan untuk mengetahui apakah pengaruh masing-masing variabel bebas yang dijadikan prediktor mempunyai hubungan linear atau tidak terhadap variabel terikat. Pengujian linearitas dilakukan dengan menggunakan test of linearity dengan bantuan SPSS versi 22 for windows. Kriterianya, jika nilai sig. Linierity di bawah 0,05 dan nilai sig. deviation from linearity di atas 0.05 maka variabel dikatakan mempunyai hubungan linear. Sebaliknya, jika nilai sig. Linierity di atas 0,05 dan nilai sig. deviation from linearity di bawah 0.05 maka variabel dikatakan mempunyai hubungan tidak linear. Rangkuman hasil linearitas dapat dilihat pada tabel 2 berikut.

Tabel 2. Ringkasan Hasil Uji Linearitas

\begin{tabular}{lllll}
\hline \multicolumn{2}{l}{ Variabel } & Sig. Linierity & Sig. Deviation from linearity & Kesimpulan \\
\cline { 1 - 4 } Bebas & Terikat & & & \\
\hline $\mathrm{X}_{1}$ & $\mathrm{Y}$ & 0,000 & 0,072 & Linear \\
\hline $\mathrm{X}_{2}$ & $\mathrm{Y}$ & 0,000 & 0,078 & Linear \\
\hline
\end{tabular}

Berdasarkan hasil yang disajikan pada Tabel 2 tersebut maka diperoleh informasi bahwa kedua variabel bebas yang dikaji dalam penelitian ini memiliki hubungan linier dengan varibel terikat yaitu percaya diri.

Uji multikolinearitas yaitu uji asumsi untuk regresi linear ganda. Asumsi dari multikolinearitas adalah bahwa variabel bebas harus terbebas dari multikolinearitas. Uji multikolinearitas dilakukan dengan melihat nilai tolerance dan variance inflation factor (VIF). Jika menggunakan alpha/tolerance $=10 \%$ atau 0,10 maka VIF $=10$. Apabila hasil yang diperoleh VIFhitung $<$ VIF $=10$ dan semua tolerance variabel bebas di atas $10 \%$, maka dapat disimpulkan tidak terjadi multikolinearitas. Berikut disajikan rangkuman hasil uji multikolinearitas.

Tabel 3. Rangkuman Hasil Multikolinearitas

\begin{tabular}{llll}
\hline Variabel & Tollerance & VIF & Kesimpulan \\
\hline $\mathrm{X}_{1}$ & 0,282 & 3,551 & Tidak terjadi \\
\hline $\mathrm{X}_{2}$ & 0,282 & 3,551 & multikolinearitas \\
\hline
\end{tabular}

Berdasarkan tabel di atas, diketahui bahwa tidak terjadi multikolinearitas di antara variabel bebas karena nilai VIF $<10(3,551<10)$ dan nilai tolerance/alpha $>0,10(0,282>0,10)$.

Pengujian hipotesis dilakukan untuk mengetahui pengaruh variabel self efficacy dan pengasuhan orang tua secara parsial dan simultan terhadap kepercayaan diri. Pengujian hipotesis dilakukan dengan mencari koefisien determinan yang digunakan untuk mengetahui tingkat ketepatan paling baik dalam analisis regresi, ini ditunjukkan oleh besarnya koefisien determinasi antara 0 (nol) dan 1 (satu). Selain itu, koefisien determinasi digunakan untuk mengetahui persentase perubahan variabel terikat $(\mathrm{Y})$ yang disebabkan oleh variabel bebas $(\mathrm{X})$. Uji koefisien determinasi dilakukan secara parsial dan simultan. Berikut rangkuman hasil uji koefisien determinasi secara parsial disajikan pada Tabel 4.

Tabel 4. Rangkuman Hasil Uji Korelasi Determinasi Parsial

\begin{tabular}{lllll}
\hline Variabel & $\begin{array}{l}\text { Koefisien } \\
\text { Korelasi Parsial }\end{array}$ & $\begin{array}{l}\text { Koefisien } \\
\text { Determinasi Parsial }\end{array}$ & $\mathbf{t}_{\text {hitung }}$ & Signifikansi \\
\hline Bila $X_{1}$ tetap & 0,219 & 0,047961 & 4,263 & 0,000 \\
\hline Bila $X_{2}$ tetapp & 0,184 & 0,033856 & 3,560 & 0,000 \\
\hline
\end{tabular}

Berdasarkan hasil pengujian tersebut diperoleh nilai $\mathrm{r}^{2}{ }_{\mathrm{x} 2 \mathrm{yx} 1}$ yaitu 0,047961 dengan thitung 4,263 dan nilai signifikansi 0,000 . Nilai signifikansi $0,000<0,05$ maka dapat dikatakan signifikan. Oleh karena itu, dapat disimpulkan bahwa Ho ditolak dan Ha diterima. Hal ini berarti terdapat pengaruh pengasuhan orang tua terhadap kepercayaan diri apabila self efficacy tetap. Selain itu, dari hasil pengujian juga diperoleh nilai $\mathrm{r}_{\mathrm{x} 2 \mathrm{yx} 1}^{2}$ yaitu 0,033856 dengan thitung 3,560 dan nilai signifikansi 0,000 . Nilai signifikansi $0,000<0,05$ maka dapat dikatakan signifikan. Oleh karena itu, dapat disimpulkan bahwa $\mathrm{H}_{0}$ ditolak dan $\mathrm{H}_{\mathrm{a}}$ diterima. Hal ini berarti terdapat pengaruh self efficacy terhadap kepercayaan diri apabila pengasuhan orang tua tetap. 
Pengujian determinasi secara simultan $\left(\mathrm{R}^{2}\right)$ dilakukan dengan bantuan SPSS versi 22 for windows. Hasil $\left(\mathrm{R}^{2}\right)$ yang diperoleh sebesar 0,355 , artinya persentase sumbangan pengaruh variabel self efficacy $\left(\mathrm{X}_{1}\right)$ dan pengasuhan orang tua $\left(\mathrm{X}_{2}\right)$ terhadap kepercayaan diri $(\mathrm{Y})$ sebesar $35,5 \% \%$, sedangkan 64,5\% dipengaruhi oleh variabel lain yang tidak diteliti dalam penelitian ini. Kemudian, untuk mengetahui apakah secara bersama-sama variabel bebas berpengaruh signifikan terhadap variabel terikat maka mencari nilai Fhitung. Dalam penelitian ini untuk mengetahui apakah variabel self efficacy dan pengasuhan orang tua berpengaruh secara signifikan atau tidak terhadap variabel kedisiplinan. Kriteria pengambilan keputusan hipotesis dalam penelitian ini nilai signifikansi $<0,05$. Berdasarkan hasil perhitungan regresi ganda dengan menggunakan bantuan SPSS versi 22 for windows diperoleh hasil $\mathrm{F}_{\text {hitung }}$ 100,444 dengan signifikansi $0,000<0,05$. Dengan demikian, dapat disimpulkan bahwa self efficacy dan pengasuhan orang tua secara bersama-sama berpengaruh signifikan terhadap kepercayaan diri siswa.

Analisis regresi ganda digunakan untuk mengetahui besar pengaruh variabel self efficacy dan pengasuhan orang tua terhadap kepercayaan diri. Persamaan regresi ganda dengan dua variabel bebas dirumuskan sebagai berikut.

$\hat{\mathrm{Y}}=18,575+0,323 \mathrm{X}_{1}+0,273 \mathrm{X}_{2}$

Nilai korelasi determinan $\left(\mathrm{R}^{2}\right)$ yang dilihat dari Adjusted $R$ Square adalah sebesar 0,355. Berdasarkan nilai korelasi determinan $\left(\mathrm{R}^{2}\right)$ dapat diketahui bobot sumbangan efektif kedua variabel secara bersama-sama yaitu 35,5\%. Selanjutnya dapat dicari sumbangan relatif dan sumbangan efektif masing-masing variabel. Hasil perhitungan sumbangan dapat dilihat pada Tabel 5 berikut ini.

Tabel 5. Ringkasan Hasil Perhitungan Sumbangan Relatif dan Sumbangan Efektif

\begin{tabular}{ccc}
\hline Variabel Bebas & \multicolumn{2}{c}{ Sumbangan (\%) } \\
\cline { 2 - 3 } & Relatif & Efektif \\
\hline Self efficacy & $54,53804571 \%$ & $19,36100623 \%$ \\
\hline Pengasuhan Orang Tua & $45,46195429 \%$ & $16,13899377 \%$ \\
\hline Total & 100 & 35,5 \\
\hline
\end{tabular}

Berdasarkan informasi pada Tabel 5, maka dapat diartikan bahwa Self Efficacy $\left(\mathrm{X}_{1}\right)$ secara tunggal mempengaruhi kepercayaan diri (Y) dengan sumbangan efektif sebesar 19,36\% sedangkan $80,64 \%$ sisanya dipengaruhi faktor lain. Selain itu, pengasuhan orang tua $\left(\mathrm{X}_{2}\right)$ secara tunggal mempengaruhi kepercayaan diri (Y) dengan sumbangan efektif sebesar 16,14\% seedangkan 83,86\% sisanya dipengaruhi faktor lain.

Hasil temuan pertama membuktikan bahwa self efficacy secara parsial berpengaruh signifikan terhadap kepercayaan diri. Hal ini menunjukkan bahwa peningkatan dan penurunan kepercayaan diri dipengaruhi oleh self efficacy siswa. Adanya pengaruh ini ditunjukkan dengan hasil koefisien determinasi parsial variabel self efficacy sebesar 3,3856\% dengan nilai signifikansi 0,000 yang berarti bahwa self efficacy secara parsial berpengaruh signifikan terhadap kepercayaan diri.

Temuan tersebut sesuai dengan pendapat Satiadarma, 2000:245) menjelaskan bahwa rasa percaya diri (self confidence) erat kaitannya dengan falsafah pemenuhan diri (self-fulfilling prophesy) dan keyakinan diri (self efficacy). Apabila seseorang yakin akan kemampuan yang ada dalam dirinya, maka ia juga akan merasa percaya diri dalam menjalankan kegiatannya.

Kepercayaan diri merupakan atribut yang paling berharga pada diri seseorang dalam kehidupan bermasyarakat. Dikarenakan dengan kepercayaan diri, seseorang mampu mengaktualisasikan segala potensi dirinya. Kepercayaan diri merupakan sebuah ekspresi atau ungkapan yang penuh semangat dan mengesankan dan dalam diri seseorang untuk menunjukkan adanya harga diri, menghargai diri sendiri, dan pemahaman terhadap dirinya sendiri (Yoder \& Procter, 1998:4).

Individu yang memiliki self efficacy tinggi menganggap kegagalan sebagai akibat dari kurangnya usaha yang keras, pengetahuan dan keterampilan. Mereka akan meningkatkan usaha mereka untuk mencegah kegagalan yang mungkin timbul. Mereka yang gagal dalam melaksanakan sesuatu, biasanya cepat mendapatkan kembali self efficacy mereka kembali setelah kegagalan tersebut. 
Individu yang memiliki self efficacy yang rendah tidak berpikir tentang bagaimana cara yang baik dalam menghadapi tugas-tugas yang sulit. Saat menghadapi tugas yang sulit mereka mengurangi usaha mereka dan cepat menyerah. Seseorang akan lambat dalam hal membenahi serta memiliki self efficacy mereka pada saat menemui kegagalan (Bandura, 1997: 119). Coleman \& Karraker (1997) menjelaskan bahwa self efficacy penting bagi manusia karena itu akan mempengaruhi emosi, pemikiran, motivasi dan perilaku manusia. Berdasarkan hasil penelitian dan pendapat di atas, secara teoritik self efficacy secara parsial memberikan pengaruh pada kepercayaan diri siswa, sehingga hasil penelitian ini menunjukkan kebenaran teori-teori yang sudah ada.

Hasil temuan pertama membuktikan bahwa pengasuhan orang tua secara parsial berpengaruh signifikan terhadap kepercayaan diri siswa. Hal ini menunjukkan bahwa peningkatan dan penurunan kepercayaan diri dipengaruhi oleh pengasuhan orang tua. Adanya pengaruh ini ditunjukkan dengan hasil koefisien determinasi parsial variabel pengasuhan orang tua sebesar $4,7961 \%$ dengan nilai signifikansi 0,000 yang berarti bahwa pengasuhan orang tua secara parsial berpengaruh signifikan terhadap kepercayaan diri.

Pola asuh orang tua mempunyai pengaruh terhadap rasa percaya diri seseorang anak. Menurut Rahman (2013: 13) orang tua dapat mengembangkan pola asuh secara positif untuk meningkatkan rasa percaya diri anak. Mengasuh secara positif adalah pergeseran dari mengasuh berdasarkan dari rasa takut menuju kearah mengasuh berdasarkan rasa cinta. Mengasuh berdasarkan rasa takut merupakan cara mengasuh tradisional dimana seseorang anak akan di hukum dengan pukulan atas kesalahan anak. Dengan hukuman tersebut anak-anak akan merasa takut dan tertekan.

Mengasuh berdasarkan cinta merupakan kebalikan dari mengasuh berdasarkan rasa takut. Mengasuh berdasarkan cinta memuaskan perhatin pada usaha memotivasi anak untuk bersikap kooperatif tanpa menggunakan rasa takut akan hukuman. Pengasuhan secara positif memusatkan perhatian pada teknik dan cara baru untuk memotivasi anak dengan cinta dan tidak dengan ketakutan akan hukuman, penghinaan, atau hilangnya rasa cinta (Nelly, 2010:6).

Menurut Middlebrook (1993:12) mengatakan ada 4 faktor yang mempengaruhi kepercayaan diri yaitu pola asuh, jenis kelamin, pendidikan dan penampilan fisik. Didikan dan asuhan yang diberikan orang tua kepada anak didalam keluarga merupakan faktor utama yang besar pengaruhnya bagi perkembangan anak dimasa mendatang. Berkaitan dengan peran jenis kelamin, yang disandangkan oleh budaya terhadap kaum pria atau perempuan memiliki efek tersendiri pada pola pengembangan kepercayaan diri. Pendidikan seringkali dijadikan tolak ukur dalam menilai keberhasilan seseorang, ini berarti semakin tinggi jenjang pendidika seseorang, maka semakin tinggi pula anggapan orang lain terhadap dirinya. Hampir menjadi anggapan umum, orang yang memiliki penampilan fisik baik dianggap memiliki watak dan sifat-sifat baik. Mereka dianggap cakap, berbudi dan berkepribadian. Sebenarnya tidak ada hubungan langsung antara penampilan fisik dengan watak dan sifat.

Kepercayaan diri anak dapat distimulasi sejak anak masih usia dini. Salah satu cara efektif yang dapat orang tua lakukan untuk melatih anak agar percaya diri adalah dengan memberikan stimulus dan motivasi kepada anak agar anak tidak takut dalam melakukan segala sesuatu tanpa anak merasa tertekan (Pratiwi, 2013: 6). Berdasarkan hasil temuan dan beberapa pendapat tersebut, secara teoritik pengasuhan orang tua secara parsial memberikan pengaruh pada kepercayaan diri siswa, sehingga hasil penelitian ini menunjukkan teori-teori yang sudah ada.

Hasil temuan pertama membuktikan bahwa self efficacay dan pengasuhan orang tua secara bersama-sama berpengaruh signifikan terhadap kepercayaan diri siswa. Hal ini menunjukkan bahwa peningkatan dan penurunan kepercayaan diri dipengaruhi oleh self efficacy dan pengasuhan orang tua. Adanya pengaruh ini ditunjukkan dengan hasil koefisien determinasi simultan sebesar 35,5\% dengan nilai signifikansi 0,000 yang berarti bahwa self efficacy dan pengasuhan orang tua secara bersama-sama berpengaruh signifikan terhadap kepercayaan diri siswa. Ketika siswa mampu menguasai self efficacy dengan baik dan mendapatkan pengasuhan orang tua dengan baik maka akan semakin baik pula kepercayaan diri siswa. Begitu pula sebaliknya, apabila siswa kurang dalam self efficacy dan kurang mendapat pengasuhan orang tua yang baik, maka tingkat kepercayaan diri siswa menjadi rendah bahkan tidak muncul.

Satiadarma (2000:245) menjelaskan bahwa perasaan percaya diri (self confidence) memiliki hubungan yang erat dengan falsafah pemenuhan diri (self-fulfilling prophesy) dan keyakinan diri (self 
efficacy). Apabila seseorang memiliki keyakinan pada kemampuan yang ada pada dirinya, maka ia juga akan merasa percaya diri untuk menjalani segala aktivitasnya.

Memberikan stimulasi yang tepat terhadap kemauan yang dimiliki anak merupakan dasar untuk menciptakan rasa percaya diri, sikap kooperatif, dan memahami perasaan. Menurut Gray (2010: 22), bahwa seorang anak yang memiliki rasa percaya diri tidak akan mudah terombangambing oleh tekanan teman sebaya, serta tidak perlu memberontak. Anak yang memiliki rasa percaya diri mampu menciptakan nasib mereka sendiri, tidak secara pasif mengikuti langkah orang lain. Kepercayaan diri merupakan atribut yang paling berharga pada diri seseorang dalam kehidupan bermasyarakat. Dikarenakan dengan kepercayaan diri, seseorang mampu mengaktualisasikan segala potensi dirinya dan mampu menciptakan nasib mereka.

Berdasarkan hasil penelitian dan pendapat tersebut, dapat disimpulkan bahwa terdapat pengaruh yang signifikan dari self efficacy dan pengaushan orang tua baik secara terpisah maupun bersama-sama terhadap kepercayaan diri. Hal ini dapat pula dikatakan bawhwa ketika semakin baik self efficacy yang dimiliki siswa, semakin baik pula kepercyaan diri siswa, semakin baik dalam pola pengasuhan orang tua yang diterima siswa, semakin baik pula kepercayaan diri siswa; serta seamik baik self efficacy dan pengasuhan orang tua, maka kepercayaan diri siswa semakin baik.

\section{SIMPULAN}

Berdasarkan hasil dan temuan penelitian ini, maka dapat disimpulkan bahwa self efficacy secara parsial berpengaruh signifikan terhadap kepercayaan diri siswa SD se-Kecamatan Kotagede. Kesimpulan ini dibuktikan dengan koefisien signifikan 0,000. Pengasuhan orang tua secara parsial berpengaruh signifikan terhadap kepercayaan diri siswa SD se-Kecamatan Kotagede. Kesimpulan ini dibuktikan dengan koefisien signifikansi 0,000. self efficacy dan pengasuhan orang tua secara simultan berpengaruh signifikan terhadap kepercayaan diri siswa SD se-Kecamatan Kotagede. Kesimpulan ini dibuktikan dengan koefisien determinasi simultan sebesar 35,5\% dengan nilai signifikansi 0,000 .

Berdasarkan simpulan penelitian, maka implikasi yang dapat disampaikan adalah self efficacy merupakan keyakinan diri seseorang atas kemampuannya dalam melakukan suatu tindakan, tugas, atau dalam mencapai suatu tujuan. Hasil penelitian ini menunjukkan bahwa self efficacy berpengaruh signifikan terhadap kepercayaan diri siswa. Hal ini mengandung implikasi agar kepercayaan diri dapat dimiliki siswa secara optimal, maka self efficacy juga harus optimal. Meskipun self efficacy muncul dari dalam diri siswa, namun orang-orang disekitar dapat juga memberikan dukkang. Pengasuhan orang tua adalah hubungan antara orang tua dengan anak yang didasari kasih sayang dan bertujuan untuk memberikan dampak positif bagi kedua belah pihak. Hasil penelitian ini menunjukkan bahwa pengasuhan orang tua berpengaruh secara signifikan terhadap kepercayaan diri siswa. Hal ini mengandung implikasi agar agar kepercayaan diri siswa dapat dimiliki secara optimal, maka orang tua perlu memberikan pengasuhan kepada anak dengan optimal.

\section{DAFTAR PUSTAKA}

Anwar, A. I. D. (2009). Hubungan antara self-efficacy dengan kecemasan berbicara di depan umum pada Mahasiswa Psikologi Universitas Sumatera Utara. Skripsi. Universitas Sumatera Utara.

Bandura, A. (1997). Self efficacy: The exercise of control. New York: W. H Freeman and Company.

Coleman, P. K., \& Karakker, K. H. (1997). Self efficacy and prenting quality: Findings and future aplication. Developmental Review, 18, 47-85.

Ghufron \& Rini. (2011). Teori-teori psikologi. Yogyakarta: Ar-Ruzz Media

Gray, J. (2010). Hubungan antara rasa percaya diri dengan ketrampilan sosial anak. Jakarta: Pustaka Belajar.

Saputri, D. I., \& Herwin, H. (2020). The effect of the spirit of nationalism and cinta tanah air on the self independence of elementary school students. JMIE (Journal of Madrasah Ibtidaiyah Education), 4(1), 114-126. 
Satiadarma, M. P. (2000). Dasar-dasar psikologi olahraga. Jakarta: Pustaka Sinar Harapan. Middlebrook. (1993). Social pshychology and modern life. New York: Alfred A, Knopft. Inc Nelly. (2010). Hubungan pola asuh orang tua dengan pembentukan kepercayaan diri anak pra sekolah di TK Aisiyah Bustanul Athfal Ketanggungan Wirobrajan Yogyakarta. Skripsi. STIKES Aisiyah Yogyakarta.

Pratiwi, H. (2013). Upaya meningkatkan rasa percaya diri anak Kelompok B melalui kegiatan bermain aktif di TK Pembina Kecamatan Bantul. Skripsi. Universitas Negeri Yogyakarta.

Rahman. (2013). Peran orang tua dalam membangun kepercayaan diri pada anak usia dini. Edukasia: Jurnal Penelitian Pendidikan Islam, 8(2), 373-388.

Yoder, J. \& Procter, W. (1998). The self-confident child. New York: Fack on Fil Publication. 